\title{
EVALUATION STUDIES ON SEEDLINGS OF SOME DATE PALMS GROWN IN EGYPT 2-EVALUATION AND SELECTION OF BARHI DATE PALM MALE SEEDLINGS UNDER ALEXANDRIA AREA CONDITIONS
}

(Received:10.4.2018)

\author{
By \\ Bahan M. Khalil, Nahla A. Awad, H. A.El-Ashry, Eman H. Afifi, A.S.M. Ismail \\ and S.A.A. Ahmed \\ Breeding Research Department for fruit Tree, Ornamental and Woody Plants, \\ Horticultural Research Institute, Agricultural Research Center, Giza, Egypt.
}

\begin{abstract}
Ten different date palm male genotypes were selected for evaluating the recommended pollinator for Barhi date palm cultivar grown in Egypt. This investigation was conducted during 2015 and 2016 seasons, at the Experimental station at El-Sabahiya, Alexandria Governorate Egypt. Spath weight with and without cover, length and width of spath with and without cover, space without strand per spath, number of strands and number of flowers per strand as well as pollen grains germination and viability percentages were determined for each male genotype. Data showed that two male trees (No. 6 and No. 7 genotypes) were superior in their morphological characters compared with the other male palms. On the other hand, there were no major differences in pollen grains viability percentage. The results of the molecular analysis of genomic DNA of the ten male palm seedlings showed that the total number of amplicons amplified by the nine primers was 184 with an average of 20.44 / primer. The polymorphism ranged between $75.0 \%$ and $100 \%$, with an average of $92.54 \%$ polymorphism. Fifteen of these amplicons were monomorphic and 169 were polymorphic. Genetic similarity value ranged between $8.3 \%$ and $11.2 \%$. The highest value (11.2\%) was between genotypes No. 5, No. 1 and No. 3 . The lowest value was recorded between genotype No. 10 and genotype No. 8. It is obvious that genetic similarity between the tested strains were very low, which may be attributed to their origin as seeds from open pollination.
\end{abstract}

Key words: Date palm male, evaluation, selection, fingerprint

\section{INTRODUCTION}

The date palm (Phoenix dactylifera L.) is one of the oldest and most important fruit trees, in Egypt and the worled. It is a monocot that has been widely cultivated for its fruits dioeciously and diploid $(2 \mathrm{n}=2 \mathrm{x}=36)$ (Marsafari and Mehrabi, 2013). (Hossein et al.2015). Artificial pollination is necessary for successful fruiting. In some date cultivars, better fruit set results from pollen of certain males than others, due to compatibility between male and females. Many investigators proved that pollen grains from different male date trees did not only influence the size and shape of seed (Xinia), but also has a direct effect on fruit set, yield and fruit physical and chemical characteristics (Metaxinia) (Ream, 1976). El-Hammady et al. (1977) reported that pollen source was found to affect fruit and seed characteristics and it exhibited metaxinic effect depending on the female genotype used, so the growers now begin to realize the need selection of males for pollination. Al-Hamoudi et al. (2006) evaluated four different date palm male genotypes to use as a pollinator for Barhi date palm cultivar grown in Egypt. Moustafa et al. (2010) studied fifty seedling palm males in order to select the suitable and most promising males to be used in pollinating date palm females. Also, Hafez et al. (2014) selected three different date palm male types namely Abo Rawash, Rashid and El Nubaria, which could be recommended to use as pollinators for Samany date palm cultivar grown at Giza Governorate. 
Benamor et al. (2014) stated that the percentage of germination for the good quality pollen is higher than $75 \%$, and the viability characteristics vary considerably from one type to another. They also stated that a high heterogeneity between the various genotypes of males contains specific characteristics.

To understand the genetic relationship among and within date palm varieties, RFLP, RAPD, SSR and AFLP markers have been used widely and eficiently to analyze the genetic diversity within and among date palm cultivars in many middle east countries such as Egypt (Soliman et al., 2003; Saker et al., 2006); Oman (Al-Ruqaish et al., 2008); Morocco Baaziz 2000; Sedra et al., 1998); Suadi Arabia (Al-Khalifah and Askari, 2003); Tunisia (Trii et al., 2000; Zehdi et al., 2004a,b); Sudan (Elshibli and Korpelainen, 2007). Some studies observed that the apparent phonotypical differences among some cultivars were not reflected in the polymorphism of the molecular markers. Obviously, many more markers should be isolated from cultivars to enhance breeding and evolutionary studies.

The aim of this study was to select a suitable pollination of Barhi cultivar under the conditions of El-Sabahiya station, Alexandria Governorate, Egypt, which represent a good genetic potential in order to multiply them vegetative and eliminate the inferior male genotypes.

\section{MATERIALS AND METHODS}

This investigation was conducted during the two successive seasons 2015 and 2016 on about eight year old trees of Barhi date palm cultivar of, planted at $7 \times 10 \mathrm{~m}^{2}$ apart in El-Sabahiya Station, Alexandria Governorate, Egypt. Several visits were carried out to select ten uniform, vigorous male date palm trees numbered from one to ten. All palm trees were healthy and subjected to the same cultural practices in both seasons under study.

\subsection{Horticultural study}

Data collected for the selected males included date of flowering, end of flowering, duration period of flowering (days) and the number of spath per tree. Morphological characters of date palm males were studied including spath weight with and without cover, weight of spath cover, length and width of spath with and without cover and space without strands / spath. The number of strands and the average number of flowers per strand were counted. Strand weight and length with and without flowers were recorded. Pollen viability and pollen germination percentages were recorded for all male palm trees under study.

\subsection{DNA Fingerprint}

\subsubsection{Inter Simple Sequence Repeats (ISSRs)}

Total DNA was extracted from young leaves as described by Porebski et al. (1997). Nine ISSR primers were used for PCR amplification (Table 1). PCR amplification was performed in a Perkin-Elmer/GeneAmp ${ }^{\circledR}$ PCR System 9700 (PE Applied Biosystems) programmed to fulfill 40 cycles after an initial denaturation cycle for $5 \mathrm{~min}$ at $94^{\circ} \mathrm{C}$. Each cycle

Table (1): Sequence of reliable ISSR primers.

\begin{tabular}{|c|c|}
\hline Primer & Sequence \\
\hline IS1 & TAT(CA) 7 C \\
\hline IS2 & CAC(TCC $)_{5}$ \\
\hline IS3 & TTT(TCC $)_{5}$ \\
\hline IS6 & $(\mathrm{GA})_{8} \mathrm{CG}$ \\
\hline IS7 & ATTA(CA) $)_{7}$ \\
\hline IS8 & $(\mathrm{AG})_{8} \mathrm{CT}$ \\
\hline IS9 & AAC(TG) ${ }_{7} \mathrm{~T}$ \\
\hline IS10 & $(\mathrm{TCC})_{5} \mathrm{AC}$ \\
\hline A9 & $\left(\mathrm{AGC}{ }_{4} \mathrm{AC}\right.$ \\
\hline
\end{tabular}

consisted of a denaturation step at $94{ }^{\circ} \mathrm{C}$ for 1 min, an annealing step at $36^{\circ} \mathrm{C}$ for $1 \mathrm{~min}$, and an elongation step at $72^{\circ} \mathrm{C}$ for $1.5 \mathrm{~min}$. The primer extension segment was extended to $7 \mathrm{~min}$ at $72^{\circ} \mathrm{C}$ in the final cycle.

The amplification products were resolved by electrophoresis in a $1.5 \%$ agarose gel containing ethidium bromide $(0.5 \mathrm{ug} / \mathrm{ml})$ in $1 \mathrm{X}$ TBE buffer at 95 volts. PCR products were visualized on UV light and photographed using a Polaroid camera. Amplified products were visually examined and the presence or absence of each, size class was scored as 1 or 0 , respectively.

\subsubsection{Data analysis of DNA fingerprint}

A similarity matrix using the similarity coefficients of Nei and $\mathrm{Li}$ (1979), was constructed for ISSR data based on the presence (coded as 1) or absence (coded as 0 ) of the resulted fragments for each primer. Moreover, the relationships among the different palm males 
as revealed by dendogram were done using SPSS windows programming (V.10) Schwartz (1978).

\subsection{Statistical analysis}

The experiment included in this study followed a completely randomized design in factorial experiment. The obtained data was subjected to analysis of variance (ANOVA) according to Snedecor and Cochran (1972). Means were differentiated by Duncan's multiple range tests at 5\% level (Duncan, 1955).

\subsection{Horticultural study}

3. RESULTS AND DISCUSSION

Data in Table (2) showed that across 2015 and 2016 the spath weight with cover ranged between 0.77 to $2.32(\mathrm{~kg})$. Male No.5 had the least weight $(0.77 \mathrm{~kg})$, in the first season. In the second season, the fifth male also gave the least value $(1.21 \mathrm{~kg})$. Concerning the weight of spath cover, males No.6\&7 gave the highest values (870.0 and $957.0 \mathrm{~g}$, respectively in 2015 and 2016). Male No.5 had the least weight (300.0 and $378.0 \mathrm{~g}$ ) in the two seasons under study. Data also cleared that the male No.6 and male No.7 recorded the highest significant weight of spath without cover, which ranged from 1147.0 to $1368.0 \mathrm{~g}$, the least was for male No.5 which had $513.3 \mathrm{~g}$ for the first season and $828.3 \mathrm{~g}$ for the second season. These findings are in line with those of Nasr et al. (1986) who selected some male date trees based on certain characteristics including weight and size of the spathes.
Table (3) and Fig.(1) showed that the highest value of spath length with cover was for male No.7 which had 91.00 and $98.33 \mathrm{~cm}$ for 2015 and 2016 seasons, respectively. The least value was given by male No.8 $(52.33 \mathrm{~cm})$, in the first season, and male No.5 $(58.67 \mathrm{~cm})$, in the second season. As for the length of spath without cover, results indicated the same trend; the male No.7 was the superior $(82.33$ and $86.00 \mathrm{~cm})$ for two seasons under study, respectively. In 2015 season, the two males (No. 5 and No. 8) had the least values (47.00 and $44.67 \mathrm{~cm}$, respectively), while in the second season (2016), male (No. 5 and No.8) had the least length $(49.67 \mathrm{~cm})$.

The highest significant width of spath with cover $(22.00$ and $21.73 \mathrm{~cm}$ ) was recorded by the male No.7 in two seasons. Meanwhile the least values $(11.00$ and $12.83 \mathrm{~cm})$ were obtained by male No. 5 in the two seasons under study. Concerning the width of spath without cover, the male No. 7 had the highest value (20.43 and $18.57 \mathrm{~cm}$ ), the male No. 5 had the least values $(09.90$ and $11.23 \mathrm{~cm})$ in the two seasons, under study, respectively.

On the other hand, the least space without strands per spath was given by the male No. 3 $(12.53 \mathrm{~cm})$ in the first season under study while the second male gave the least value $(11.83 \mathrm{~cm})$, in the second season.

All these results are in harmony with those found by El-Hammady et al. (1977), AlHamoudi et al. (2006) and Farag et al. (2012) who reported that there was a positive correlation between fruit set percentage and

Table (2): Means of spath weight cover, spath with cover weight and weight of spath without cover for all pollinators in 2015 and 2016 seasons.

\begin{tabular}{|c|c|c|c|c|c|c|}
\hline \multirow{2}{*}{$\begin{array}{c}\text { Male } \\
\text { number }\end{array}$} & \multicolumn{2}{|c|}{$\begin{array}{c}\text { Spath weight with cover } \\
(\mathbf{k g})\end{array}$} & \multicolumn{2}{c|}{$\begin{array}{c}\text { Spath cover weight } \\
(\mathbf{g})\end{array}$} & \multicolumn{2}{c|}{ Weight spath of without cover (g) } \\
\cline { 2 - 7 } & $\mathbf{2 0 1 5}$ & $\mathbf{2 0 1 6}$ & $\mathbf{2 0 1 5}$ & $\mathbf{2 0 1 6}$ & $\mathbf{2 0 1 5}$ & $\mathbf{2 0 1 6}$ \\
\hline $\mathbf{1}$ & $1.85 \mathrm{BC}$ & $1.93 \mathrm{~B}$ & $866.7 \mathrm{~A}$ & $886.7 \mathrm{AB}$ & $983.3 \mathrm{BC}$ & $1047 \mathrm{BCD}$ \\
\hline $\mathbf{2}$ & $1.59 \mathrm{CD}$ & $1.54 \mathrm{D}$ & $680.0 \mathrm{~B}$ & $653.3 \mathrm{C}$ & $913.3 \mathrm{BCD}$ & $886.7 \mathrm{CD}$ \\
\hline $\mathbf{3}$ & $1.68 \mathrm{BCD}$ & $1.89 \mathrm{~B}$ & $723.3 \mathrm{~B}$ & $833.3 \mathrm{AB}$ & $956.7 \mathrm{BC}$ & $1080 \mathrm{BC}$ \\
\hline $\mathbf{4}$ & $1.15 \mathrm{E}$ & $1.62 \mathrm{CD}$ & $500.0 \mathrm{C}$ & $666.7 \mathrm{C}$ & $680.0 \mathrm{DE}$ & $950 \mathrm{CD}$ \\
\hline $\mathbf{5}$ & $0.77 \mathrm{~F}$ & $1.21 \mathrm{E}$ & $300.0 \mathrm{D}$ & $378.3 \mathrm{D}$ & $513.3 \mathrm{E}$ & $828.3 \mathrm{D}$ \\
\hline $\mathbf{6}$ & $2.00 \mathrm{AB}$ & $2.28 \mathrm{~A}$ & $870.0 \mathrm{~A}$ & $920.0 \mathrm{AB}$ & $1147 \mathrm{AB}$ & $1357 \mathrm{~A}$ \\
\hline $\mathbf{7}$ & $2.19 \mathrm{~A}$ & $2.32 \mathrm{~A}$ & $926.7 \mathrm{~A}$ & $957.0 \mathrm{~A}$ & $1260 \mathrm{~A}$ & $1368 \mathrm{~A}$ \\
\hline $\mathbf{8}$ & $1.43 \mathrm{DE}$ & $1.52 \mathrm{D}$ & $486.7 \mathrm{C}$ & $586.7 \mathrm{C}$ & $940.0 \mathrm{BCD}$ & $933.3 \mathrm{CD}$ \\
\hline $\mathbf{9}$ & $1.70 \mathrm{BCD}$ & $1.98 \mathrm{~B}$ & $726.7 \mathrm{~B}$ & $806.7 \mathrm{~B}$ & $970.0 \mathrm{BC}$ & $1177 \mathrm{AB}$ \\
\hline $\mathbf{1 0}$ & $1.58 \mathrm{CD}$ & $1.84 \mathrm{BC}$ & $720.0 \mathrm{~B}$ & $901.7 \mathrm{AB}$ & $856.7 \mathrm{CD}$ & $935 \mathrm{CD}$ \\
\hline
\end{tabular}

Means in the same column followed by the same letter(s) are not significantly $(\mathrm{p} \geq 0.05)$ different. 
bunch weight obtained at harvest.

Data in Table (4) showed the number of strands per spath of ten male palms under study. In the first season (2015), the highest number was shown by only the male No.7 (190.0), while in the second season (2016), was shown by three males, No. 1, No. 6 and No.7, ranging from 197.0 to 202.7. The male No.5 had the least number of strands per spath (94.3 and 112.7), in the two seasons, respectively. Data indicated that the highest weight of strand was for the male No. 7 (4.77 and $4.53 \mathrm{~g}$ ), for two seasons under from 73.13 to 82.47 flowers in the two seasons 2015 and 2016. The least number of flowers per strand was shown by the male No.4 (42.33 and 41.67) in the same two seasons (2015 and 2016).

Regarding the strand length, the obtained results in Table (4) showed that the highest value was for male No.6 $(22.67 \mathrm{~cm})$ in the first season. In the second season, there were four males ( No. 1, 3, 6 and 7) which had the highest values ranging from 20.83 to $22.83 \mathrm{~cm}$. Data revealed that the least space length without flowers was for the male No.7 $(1.70 \mathrm{~cm})$ in season 2015 , and

Table (3): Means of length of spath with and without cover, width of spath with and without cover and space without strands/spath for all pollinators in $2015-2016$.

\begin{tabular}{|c|c|c|c|c|c|c|c|c|c|c|}
\hline \multirow{2}{*}{$\begin{array}{c}\text { Male } \\
\text { number }\end{array}$} & $\begin{array}{c}\text { Length of spath with } \\
\text { cover } \mathbf{( c m})\end{array}$ & \multicolumn{2}{c|}{$\begin{array}{c}\text { Length of spath } \\
\text { without cover }(\mathbf{c m})\end{array}$} & \multicolumn{2}{c|}{$\begin{array}{c}\text { Width of spath with } \\
\text { cover }(\mathbf{c m})\end{array}$} & \multicolumn{2}{c|}{$\begin{array}{c}\text { Width of spath } \\
\text { without cover }(\mathbf{c m})\end{array}$} & \multicolumn{2}{c|}{$\begin{array}{c}\text { Space without } \\
\text { strands/spath }(\mathbf{c m})\end{array}$} \\
\cline { 2 - 13 } & $\mathbf{2 0 1 5}$ & $\mathbf{2 0 1 6}$ & $\mathbf{2 0 1 5}$ & $\mathbf{2 0 1 6}$ & $\mathbf{2 0 1 5}$ & $\mathbf{2 0 1 6}$ & $\mathbf{2 0 1 5}$ & $\mathbf{2 0 1 6}$ & $\mathbf{2 0 1 5}$ & $\mathbf{2 0 1 6}$ \\
\hline $\mathbf{1}$ & $81.67 \mathrm{AB}$ & $86.33 \mathrm{~B}$ & $70.40 \mathrm{~B}$ & $77.67 \mathrm{~B}$ & $15.83 \mathrm{CD}$ & $16.57 \mathrm{DE}$ & $15.07 \mathrm{C}$ & $15.23 \mathrm{C}$ & $15.30 \mathrm{CD}$ & $13.67 \mathrm{D}$ \\
\hline $\mathbf{2}$ & $66.50 \mathrm{C}$ & $63.00 \mathrm{DEF}$ & $57.00 \mathrm{CD}$ & $54.67 \mathrm{EF}$ & $15.17 \mathrm{CD}$ & $15.60 \mathrm{EF}$ & $14.37 \mathrm{CD}$ & $14.10 \mathrm{C}$ & $16.17 \mathrm{C}$ & $11.83 \mathrm{E}$ \\
\hline $\mathbf{3}$ & $71.33 \mathrm{BC}$ & $70.33 \mathrm{CD}$ & $62.67 \mathrm{BCD}$ & $59.33 \mathrm{DE}$ & $15.67 \mathrm{CD}$ & $16.03 \mathrm{DE}$ & $14.60 \mathrm{C}$ & $14.90 \mathrm{C}$ & $12.53 \mathrm{~F}$ & $13.17 \mathrm{D}$ \\
\hline $\mathbf{4}$ & $74.67 \mathrm{BC}$ & $73.00 \mathrm{C}$ & $65.67 \mathrm{BC}$ & $63.00 \mathrm{CD}$ & $12.50 \mathrm{DE}$ & $14.57 \mathrm{~F}$ & $11.40 \mathrm{DE}$ & $12.77 \mathrm{D}$ & $19.37 \mathrm{~B}$ & $17.10 \mathrm{~B}$ \\
\hline $\mathbf{5}$ & $53.67 \mathrm{DE}$ & $58.67 \mathrm{~F}$ & $47.00 \mathrm{E}$ & $49.67 \mathrm{~F}$ & $11.00 \mathrm{E}$ & $12.83 \mathrm{G}$ & $09.90 \mathrm{E}$ & $11.23 \mathrm{E}$ & $15.03 \mathrm{CD}$ & $15.93 \mathrm{C}$ \\
\hline $\mathbf{6}$ & $62.33 \mathrm{CDE}$ & $77.00 \mathrm{C}$ & $55.67 \mathrm{D}$ & $68.67 \mathrm{C}$ & $20.00 \mathrm{AB}$ & $18.77 \mathrm{C}$ & $18.63 \mathrm{AB}$ & $17.10 \mathrm{~B}$ & $15.27 \mathrm{CD}$ & $13.83 \mathrm{D}$ \\
\hline $\mathbf{7}$ & $91.00 \mathrm{~A}$ & $98.33 \mathrm{~A}$ & $82.33 \mathrm{~A}$ & $86.00 \mathrm{~A}$ & $22.00 \mathrm{~A}$ & $21.73 \mathrm{~A}$ & $20.43 \mathrm{~A}$ & $18.57 \mathrm{~A}$ & $13.23 \mathrm{EF}$ & $17.07 \mathrm{~B}$ \\
\hline $\mathbf{8}$ & $52.33 \mathrm{E}$ & $68.00 \mathrm{CDE}$ & $44.67 \mathrm{E}$ & $58.67 \mathrm{DE}$ & $17.33 \mathrm{BC}$ & $20.40 \mathrm{~B}$ & $15.90 \mathrm{BC}$ & $18.03 \mathrm{AB}$ & $16.17 \mathrm{C}$ & $16.83 \mathrm{~B}$ \\
\hline $\mathbf{9}$ & $65.67 \mathrm{CD}$ & $76.00 \mathrm{C}$ & $56.00 \mathrm{D}$ & $68.00 \mathrm{C}$ & $16.00 \mathrm{CD}$ & $16.97 \mathrm{D}$ & $14.70 \mathrm{C}$ & $14.83 \mathrm{C}$ & $14.50 \mathrm{DE}$ & $15.87 \mathrm{C}$ \\
\hline $\mathbf{1 0}$ & $65.67 \mathrm{CD}$ & $60.67 \mathrm{EF}$ & $58.67 \mathrm{CD}$ & $52.67 \mathrm{EF}$ & $15.23 \mathrm{CD}$ & $16.37 \mathrm{DE}$ & $14.27 \mathrm{CD}$ & $14.10 \mathrm{C}$ & $20.87 \mathrm{~A}$ & $21.20 \mathrm{~A}$ \\
\hline
\end{tabular}

Means in the same column followed by the same letter(s) are not significantly ( $p \geq 0.05)$ different.

Table (4): Means number of strands/spath, strand weight, average number of flowers / strand length and space length without flowers for all pollinators in 2015 and 2016 seasons.

\begin{tabular}{|c|c|c|c|c|c|c|c|c|c|c|}
\hline \multirow{2}{*}{$\begin{array}{c}\text { Male } \\
\text { number }\end{array}$} & \multicolumn{2}{|c|}{$\begin{array}{c}\text { Number of } \\
\text { strands/spath }\end{array}$} & \multicolumn{2}{|c|}{ Strand weight $(\mathrm{gm})$} & \multicolumn{2}{|c|}{$\begin{array}{l}\text { Average number of } \\
\text { flowers/strand }\end{array}$} & \multicolumn{2}{|c|}{ Strand length $(\mathrm{cm})$} & \multicolumn{2}{|c|}{$\begin{array}{c}\text { Space length } \\
\text { without flowers }\end{array}$} \\
\hline & 2015 & 2016 & 2015 & 2016 & 2015 & 2016 & 2015 & 2016 & 2015 & 2016 \\
\hline 1 & $165.3 \mathrm{~B}$ & $199.3 \mathrm{~A}$ & $3.56 \mathrm{CD}$ & $3.83 \mathrm{BC}$ & $60.94 \mathrm{BC}$ & 62.00CD & $20.35 \mathrm{ABC}$ & $21.97 \mathrm{~A}$ & $2.43 \mathrm{CDE}$ & $2.93 \mathrm{BC}$ \\
\hline 2 & 111.7CDE & 119.3DE & $2.70 \mathrm{DE}$ & $2.27 \mathrm{~F}$ & $64.11 \mathrm{AB}$ & $67.67 \mathrm{BC}$ & $18.33 \mathrm{BCD}$ & $18.37 \mathrm{~B}$ & 3.83B & $4.77 \mathrm{~A}$ \\
\hline 3 & $135.3 \mathrm{C}$ & $159.3 \mathrm{BC}$ & $2.82 \mathrm{DE}$ & $2.80 \mathrm{EF}$ & $58.15 \mathrm{BC}$ & $60.67 \mathrm{D}$ & $21.87 \mathrm{AB}$ & $22.13 \mathrm{~A}$ & $1.90 \mathrm{DE}$ & $2.77 \mathrm{CD}$ \\
\hline 4 & $104.3 \mathrm{DE}$ & $125.7 \mathrm{D}$ & $4.47 \mathrm{AB}$ & $4.03 \mathrm{AB}$ & $42.33 \mathrm{D}$ & $41.67 \mathrm{~F}$ & $15.43 \mathrm{D}$ & $.17 \mathrm{C}$ & $3.67 \mathrm{~B}$ & $3.43 \mathrm{~B}$ \\
\hline 5 & $94.3 \mathrm{E}$ & $112.7 \mathrm{E}$ & $3.61 \mathrm{BCD}$ & $3.47 \mathrm{CD}$ & $50.41 \mathrm{BCD}$ & $52.00 \mathrm{E}$ & $14.71 \mathrm{D}$ & $13.50 \mathrm{D}$ & $2.67 \mathrm{C}$ & $2.87 \mathrm{C}$ \\
\hline 6 & $162.3 \mathrm{~B}$ & $197.0 \mathrm{~A}$ & $4.27 \mathrm{ABC}$ & $4.10 \mathrm{AB}$ & $77.30 \mathrm{~A}$ & $82.47 \mathrm{~A}$ & $22.67 \mathrm{~A}$ & $22.83 \mathrm{~A}$ & $2.50 \mathrm{CD}$ & $3.00 \mathrm{BC}$ \\
\hline 7 & $190.0 \mathrm{~A}$ & $202.7 \mathrm{~A}$ & $4.77 \mathrm{~A}$ & $4.53 \mathrm{~A}$ & $75.58 \mathrm{~A}$ & $73.13 \mathrm{~B}$ & $20.20 \mathrm{ABC}$ & $20.83 \mathrm{~A}$ & $1.70 \mathrm{E}$ & $2.30 \mathrm{D}$ \\
\hline 8 & 127.7CD & $151.3 \mathrm{C}$ & $2.60 \mathrm{E}$ & $2.80 \mathrm{EF}$ & $52.21 \mathrm{BCD}$ & $52.23 \mathrm{E}$ & $17.73 \mathrm{CD}$ & $16.33 \mathrm{C}$ & $4.73 \mathrm{~A}$ & $4.57 \mathrm{~A}$ \\
\hline 9 & $128.0 \mathrm{CD}$ & $156.0 \mathrm{BC}$ & $3.10 \mathrm{DE}$ & $3.23 \mathrm{DE}$ & $54.60 \mathrm{BCD}$ & $57.53 \mathrm{DE}$ & $10.50 \mathrm{E}$ & 11.77D & $1.93 \mathrm{CDE}$ & $2.97 \mathrm{BC}$ \\
\hline 10 & $117.7 \mathrm{CDE}$ & $165.7 \mathrm{~B}$ & $2.83 \mathrm{DE}$ & $3.07 \mathrm{DE}$ & $47.06 \mathrm{CD}$ & $51.93 \mathrm{E}$ & $17.60 \mathrm{CD}$ & $17.10 \mathrm{BC}$ & $3.67 \mathrm{~B}$ & $3.10 \mathrm{BC}$ \\
\hline
\end{tabular}

Means in the same column followed by the same letter(s) are not significantly ( $p \geq 0.05)$ different.

study, respectively, the least weight of strand was for the male No. 8 (2.60 g), in 2015 and for male No. 2 (2.27 g).

As for the mean number of flowers per strand, data in Table (4) revealed that the males No,6 and No.7 had the highest number ranging
$(2.30 \mathrm{~cm})$ in season 2016 . These results are in harmony with those reported by Benamor et al. (2014) who stated that male palm trees are in a good state for all the descriptive parameters held by farmers (well localized, early and producing a great number of spathes). 
Table (5): Means of Pollen grains weight per strand, pollen viability and pollen germination percentages for all pollinators in 2015 and 2016 season.

\begin{tabular}{|c|c|c|c|c|c|c|}
\hline \multirow{2}{*}{$\begin{array}{c}\text { Male } \\
\text { number }\end{array}$} & \multicolumn{2}{|c|}{$\begin{array}{c}\text { Pollen grains weight per } \\
\text { strand (g) }\end{array}$} & \multicolumn{2}{c|}{ Pollen viability \% } & \multicolumn{2}{c|}{ Pollen germination \% } \\
\cline { 2 - 7 } & $\mathbf{2 0 1 5}$ & $\mathbf{2 0 1 6}$ & $\mathbf{2 0 1 5}$ & $\mathbf{2 0 1 6}$ & $\mathbf{2 0 1 5}$ & $\mathbf{2 0 1 6}$ \\
\hline $\mathbf{1}$ & $0.267 \mathrm{AB}$ & $0.327 \mathrm{~B}$ & $91.47 \mathrm{~A}$ & $93.03 \mathrm{AB}$ & $50.67 \mathrm{AB}$ & $52.50 \mathrm{BC}$ \\
\hline $\mathbf{2}$ & $0.160 \mathrm{BC}$ & $0.200 \mathrm{C}$ & $89.63 \mathrm{~A}$ & $89.90 \mathrm{~B}$ & $49.94 \mathrm{AB}$ & $52.40 \mathrm{BC}$ \\
\hline $\mathbf{3}$ & $0.303 \mathrm{~A}$ & $0.347 \mathrm{~B}$ & $92.80 \mathrm{~A}$ & $93.03 \mathrm{AB}$ & $45.15 \mathrm{BC}$ & $48.07 \mathrm{CD}$ \\
\hline $\mathbf{4}$ & $0.167 \mathrm{BC}$ & $0.197 \mathrm{C}$ & $91.57 \mathrm{~A}$ & $89.17 \mathrm{~B}$ & $30.07 \mathrm{D}$ & $42.17 \mathrm{E}$ \\
\hline $\mathbf{5}$ & $0.123 \mathrm{C}$ & $0.153 \mathrm{C}$ & $91.23 \mathrm{~A}$ & $93.43 \mathrm{AB}$ & $37.07 \mathrm{CD}$ & $42.73 \mathrm{E}$ \\
\hline $\mathbf{6}$ & $0.343 \mathrm{~A}$ & $0.437 \mathrm{~A}$ & $95.47 \mathrm{~A}$ & $92.97 \mathrm{AB}$ & $59.65 \mathrm{~A}$ & $60.13 \mathrm{~A}$ \\
\hline $\mathbf{7}$ & $0.377 \mathrm{~A}$ & $0.363 \mathrm{AB}$ & $92.67 \mathrm{~A}$ & $95.83 \mathrm{~A}$ & $55.53 \mathrm{AB}$ & $60.20 \mathrm{~A}$ \\
\hline $\mathbf{8}$ & $0.127 \mathrm{C}$ & $0.147 \mathrm{C}$ & $94.33 \mathrm{~A}$ & $92.10 \mathrm{AB}$ & $37.43 \mathrm{CD}$ & $43.83 \mathrm{DE}$ \\
\hline $\mathbf{9}$ & $0.103 \mathrm{C}$ & $0.170 \mathrm{C}$ & $91.47 \mathrm{~A}$ & $90.60 \mathrm{AB}$ & $32.68 \mathrm{CD}$ & $44.20 \mathrm{DE}$ \\
\hline $\mathbf{1 0}$ & $0.143 \mathrm{C}$ & $0.203 \mathrm{C}$ & $93.47 \mathrm{~A}$ & $94.37 \mathrm{AB}$ & $52.83 \mathrm{AB}$ & $53.97 \mathrm{~B}$ \\
\hline
\end{tabular}

Means in the same column followed by the same letter(s) are not significantly ( $\mathrm{p} \geq 0.05)$ different.

Data in Table (5) presented the mean of pollen grains weight per strand, pollen viability and pollen germination. Regarding the weight of pollen grains, the three males trees (No.3, 6, and 7) had the highest values ranging from 0.303 to $0.377 \mathrm{~g}$, in the first season. In the second season one male only (No.6) had the highest weight 0.437 g. The males (No.5,8,9 and 10 ) had the least values of pollen grains weight ranging from 0.103 to $0.203 \mathrm{~g}$ in the two seasons 2015 and 2016, respectively.

In the case of pollen viability, data in Table (5) showed no significant differences among ten male trees in the first season (2015), while there were slight differences in the second season. In the same Table, it was clear that the sixth and seventh male trees had the highest values of pollen germination ranging between 55.53 and $60.20 \%$, in two seasons 2015 and 2016. The lowest value of pollen germination for male No. $4(30.07 \%)$ in the first season and by the two males (No. 4 and No. 5), which gave 42.17 and $42.73 \%$, respectively in the second season. Zeinab et al. (2014) selected five male pollenizers according to pollen grains weight and their viability in Siwa Oasis. Benamor et al. (2014) reported that the percentage of germination for good quality pollen is higher than $75 \%$ and the viability characteristics vary considerably from one genotype to another. AlHammoudi et al. (2006) stated that there were great differences in pollen grains germination percentage in four male trees.

Concerning the period of flowering, Table (6) showed that it was shorter in the first season (2015) than in the second season (2016) for all males palm trees under study. We noticed that the sixth and seventh male had the longest period of flowering ranging between 69 to 92 days in the two seasons. It was evident that the male palm trees (sixth, seventh and tenth) had the highest number of spathes ranging between 22 and 24 spath per male in two seasons under study. These results are in agreement with those reported by Benamor et al. (2014), who considered that the "Male" flowering period is seldom extended until the month of May.

\subsubsection{Polymorphism and genetic similarity estimated by ISSR markers}

Table (7) summarizes the results obtained from using nine primers of ISSR markers. All of the nine tested primers were reproducible and scorable Fig.(2) using (Ladder molecular weight marker (with a range 100-3000 bp). Four primers produced $100 \%$ polymorphic amplicons (1,2, 3 and 5). On the other hand, primers No.8 and 4 recorded the highest percentage of polymorphism (92.9 and 91.3, respectively). The average of percentages was $92.54 \%$. Primer No.6 produced the highest number of amplicons (29), four of these amplicons were monomorphic, while, twentyfive were polymorphic. The total number produced by the nine primers was 184 amplicons, fifteen of which were monomorphic and 169 were polymorphic. In this regard, Ameer et al. (2016) stated that, using of seven ISSR primers for twenty five date palm cultivars produced total scorable bands of 622 with an average of 38.8 bands per primer. Meanwhile, Abd-Alla (2010) mentioned that DNA bands generated with the ISSR primer (HB-15) ranged from 7 to 9. Moreover, primer (HB-10) produced 

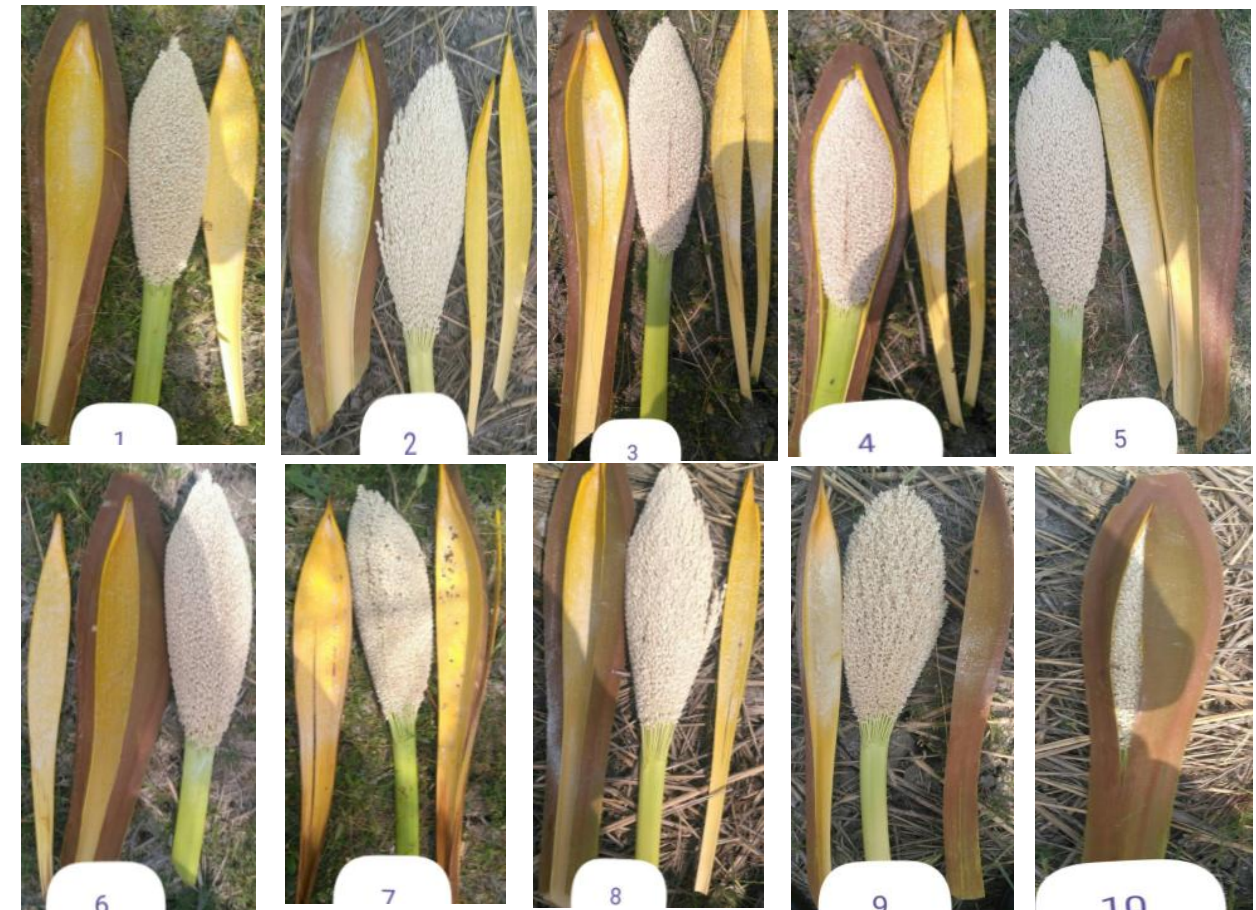

Fig. (1): Spath of ten seedlings of date palm males under study.
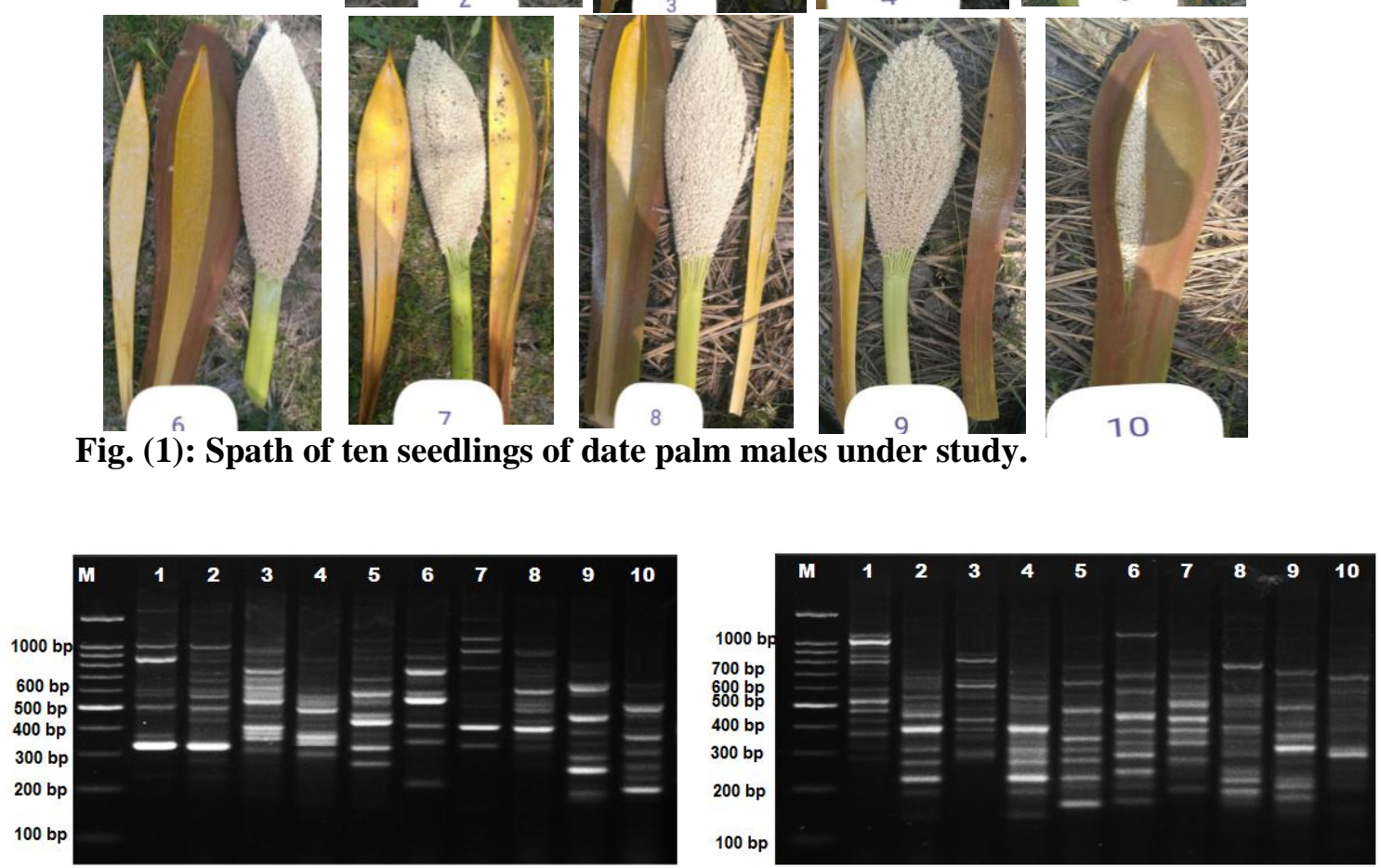

Fig.(2):Polymorphism detected by ISSR (IS1 and IS3) marker for ten selected date palm males. M: Ladder molecular weight marker.

Table (6): Means of first spath date, last spath date, period day and the number of spathes/male for all pollinators in 2015 and 2016 seasons.

\begin{tabular}{|c|c|c|c|c|c|c|c|c|}
\hline $\begin{array}{c}\text { Male } \\
\text { number }\end{array}$ & \multicolumn{2}{|c|}{ First spath date } & \multicolumn{2}{c|}{ Last spath date } & \multicolumn{2}{c|}{ Period (days) } & \multicolumn{2}{c|}{$\begin{array}{c}\text { Number of spathes } \\
\text { /male }\end{array}$} \\
\hline & $\mathbf{2 0 1 5}$ & $\mathbf{2 0 1 6}$ & $\mathbf{2 0 1 5}$ & $\mathbf{2 0 1 6}$ & $\mathbf{2 0 1 5}$ & $\mathbf{2 0 1 6}$ & $\mathbf{2 0 1 5}$ & $\mathbf{2 0 1 6}$ \\
\hline $\mathbf{1}$ & 25 Jan. & 16 Jan. & 16 Apr. & 15 Apr. & 81 & 90 & 16 & 18 \\
\hline $\mathbf{2}$ & 21 Nar. & 2 Mar. & 11 Apr. & 9 Apr. & 41 & 38 & 14 & 12 \\
\hline $\mathbf{3}$ & 2 Feb. & 2 Feb. & 21 Apr. & 15 Apr. & 78 & 73 & 16 & 14 \\
\hline $\mathbf{4}$ & 1 Mar. & 1 Mar. & 16 Apr. & 1 Mar. & 46 & 61 & 18 & 18 \\
\hline $\mathbf{5}$ & 1 Apr. & 3 Mar. & 2 May. & 26 Apr. & 31 & 54 & 14 & 20 \\
\hline $\mathbf{6}$ & 11 Feb. & 2 Feb. & 22 Apr. & 2 May. & 70 & 90 & 22 & 23 \\
\hline $\mathbf{7}$ & 30 Jan. & 25 Jan. & 9 Apr. & 26 Apr. & 69 & 92 & 23 & 22 \\
\hline $\mathbf{8}$ & 22 Feb. & 2 Feb. & 21 Apr. & 26 Apr. & 58 & 84 & 12 & 10 \\
\hline $\mathbf{9}$ & 1 Mar. & 2 Feb. & 11 Apr. & 15 Apr. & 41 & 73 & 15 & 18 \\
\hline $\mathbf{1 0}$ & 8 Feb. & 12 Feb. & 1 May. & 1 May. & 82 & 79 & 24 & 20 \\
\hline
\end{tabular}

Means in the same column followed by the same letter(s) are not significantly ( $p \geq 0.05)$ different. 
Table (7): Number of monomorphic bands, number of polymorphic band, total number of bands and percentage polymorphism of ten date palm males.

\begin{tabular}{|c|c|c|c|c|c|}
\hline $\begin{array}{c}\text { Primer } \\
\text { No. }\end{array}$ & $\begin{array}{c}\text { Primer } \\
\text { name }\end{array}$ & $\begin{array}{c}\text { Monomorphic } \\
\text { bands }\end{array}$ & $\begin{array}{c}\text { number of } \\
\text { polymorphic bands }\end{array}$ & $\begin{array}{c}\text { Total number } \\
\text { of bands }\end{array}$ & $\begin{array}{c}\text { percentage of } \\
\text { polymorphic } \\
\text { bands }\end{array}$ \\
\hline $\mathbf{1}$ & IS1 & 0 & 25 & 25 & 100 \\
$\mathbf{2}$ & IS2 & 0 & 20 & 20 & 100 \\
$\mathbf{3}$ & IS3 & 0 & 18 & 18 & 100 \\
$\mathbf{4}$ & IS6 & 2 & 21 & 23 & 91.3 \\
$\mathbf{5}$ & IS7 & 0 & 15 & 15 & 100 \\
$\mathbf{6}$ & IS8 & 4 & 25 & 29 & 86.2 \\
$\mathbf{7}$ & IS9 & 2 & 14 & 16 & 87.5 \\
$\mathbf{8}$ & IS10 & 1 & 13 & 14 & 92.9 \\
$\mathbf{9}$ & A9 & 6 & 18 & 24 & 75.0 \\
\hline Total & & 15 & 169 & 184 & \\
\hline Mean & & 1.66 & 18.77 & 20.44 & $92.54 \%$ \\
\hline
\end{tabular}

Table (8): Genetic similarity matrixes computed according to Dice Coefficient from ISSR marker.

\begin{tabular}{|l|l|l|l|l|l|l|l|l|l|}
\hline D1 & & & & & & & & \\
\hline D2 & 10.3 & & & & & & & & \\
\hline D3 & 11.0 & 10.7 & & & & & & & \\
\hline D4 & 9.90 & 9.40 & 9.90 & & & & & & \\
\hline D5 & 11.2 & 11.1 & 11.2 & 10.7 & & & & & \\
\hline D6 & 10.5 & 10.0 & 10.5 & 9.40 & 10.7 & & & & \\
\hline D7 & 10.1 & 9.40 & 10.5 & 9.20 & 10.7 & 9.40 & & & \\
\hline D8 & 9.40 & 9.10 & 10.0 & 8.90 & 10.2 & 9.10 & 8.90 & & \\
\hline D9 & 10.2 & 9.90 & 10.6 & 9.50 & 10.6 & 10.1 & 9.70 & 9.00 & \\
\hline D10 & 9.50 & 9.40 & 9.90 & 8.80 & 9.90 & 9.00 & 9.00 & 8.30 & 9.10 \\
\hline
\end{tabular}

(D) Represented male genotypes.

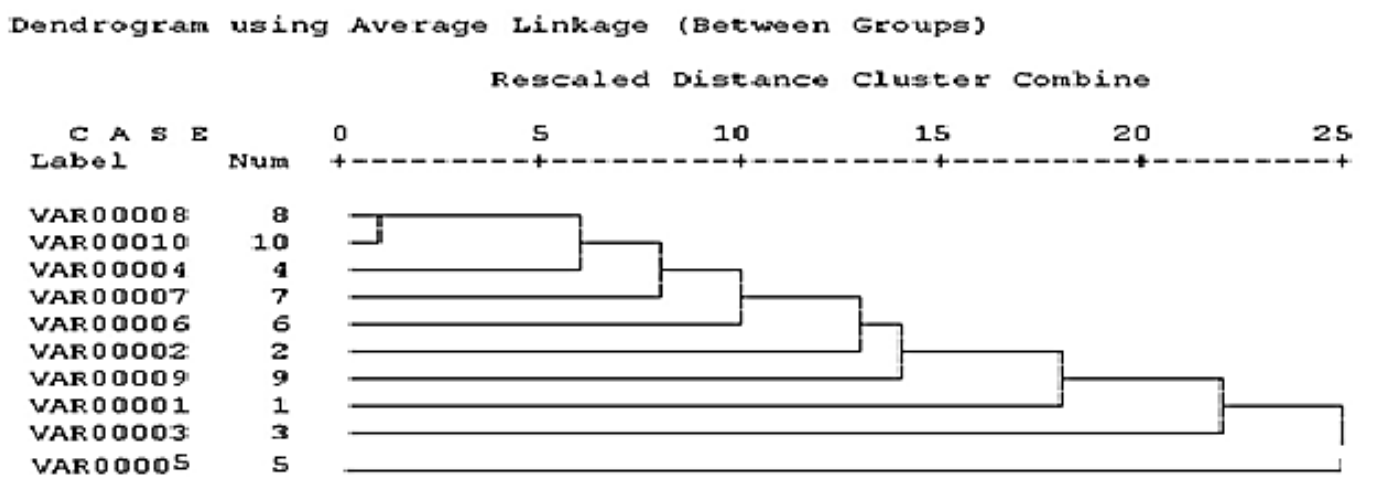

Fig.(3): Dendrogram using average linkage(between groups)

DNA bands with molecular weight of 400-900 bp.

Genetic similarity was estimated according to Dice coefficient (Sneath and Sokal 1973). The genetic similarity ranged from $8.3 \%$ to $11.2 \%$ (Table 8). The highest genetic similarity $11.2 \%$ ) was between male No.5 and males No.1 and 3 . However, the lowest genetic similarity was recorded between male No.10 and male No.8. It is obvious that genetic similarity between the tested males was very low; this may be attributed to its origin as seeds. In this respect, Hamza et al. (2012), observed the highest (48\%) and the lowest $(5 \%)$ genetic distance among date palm cultivars based on ISSR data, interestingly 
the highest and lowest genetic similarities have divided the date palm cultivars geographically.

\subsubsection{Cluster analysis}

Dendrogram obtained from UPGMA cluster analysis of genetic distances (Fig. 3) revealed that, all of the tested genotypes were separated into nine clusters. Each cluster includes one male only. However, one cluster grouped males No.8 and10. ISSR has proved successful for assessing genetic diversity within various plant groups for gene mapping and for germplasm identification (Santos et al. 2011).

\section{Conclusion}

The results clearly indicated that males No.6 \& 7 genotype were superior in their morphological characters, in Alexandria area. parameters.

Moreover, fair quality males of the studied palm trees may give a good performance, in other climatic conditions.

\section{REFERENCES}

Abd-Alla M.M. (2010). Genetic stability of Phoenix dactylifera var. Karama produced In vitro. New York Sci. J., 3(12): 70-75.

Al-Hamoudi A.H., El-Hammady A.M., Desouky L.M. and Abdel-Hamid A. (2006). Evaluation of some male types as pollinators for Barhi date palm cv. Grown in Egypt. Arab. Univ. J. Agric. Sci., Ain Shams Univ., Cairo, Egypt, 14 (1): 365377.

Al-Ruqaishi I.A., Davey M., Alderson P. and Mayes S. (2008). Genetic relationships and genotype tracing in date palms (Phoenix dactylifera L.) in Oman, based on microsatellite markers. Plant Genetic resources. 61: 70-72.

Al-Khalifah N.S. and Askari E. (2003). Molecular phylogeny of date palm (Phoenix dactylifera L.) cultivars from Saudi Arabia by DNA ingerprinting. theor. Appl. Genet. 107(7): 1266-70.

Ameer A.M., Saifullah K., Sarwar M.G., Naheed K. and Rafat S. (2016). DNA fingerprinting of some Pakistani date palm (Phoenix dactylifera L.) cultivars using ISSR markers. pak. J. Bot., 48(5): 20052010.

Baaziz M. (2000). Date palm culture in the Maghreb countries: constraints and scientiic research. Paper presented at the date palm international symposium, Namibia, 22-25 February 2000, pp 306311.

Benamor B., Boughediri L. and Ghala A. (2014). Selection of male date palms (Phoenix dactylifera L.) at Daouia station (Oued Souf, Algeria). Ad. in Environ. Biol., 8 (24): 29-36.

Duncan D.B. (1955). Multiple range and multiple F tests. Biometrics, 11:1-42.

El-Hammady M.M., Khalifa A.S. and ElHammady A.M. (1977). The effect of date pollen on some physical and chemical characters of "Hayani" variety. Res. Bull. No. 733, Fac. Agric., Ain Shams Univ., Cairo, Egypt.

Elshibli S. and Korpelainen H. (2007). Microsatellite markers reveal high genetic diversity in date palm (Phoenix dactylifera L.) germplasm from sudan. Genetica 134: 251-260.

Farag K.M., El-Sabagh A.S. and El-Ashry H.A. (2012). Fruit charactersties of Zaghloul date palm in relation to metazenic influences of used pollinator. Amer. Eurasian J. Agric. Environ. Sci., 12: 842855.

Hafez O.M., Malaka A. Saleh, Mostafa E.A.M., Naguib M.M. and Ashour N.E. (2014). Effect of pollen grain sources on yield and fruit quality of Samany date palm. Int $1 \mathrm{~J}$. of Agric. Res. 9 (3): 164-168.

Hamza H., BenAbderrahim M.A., Elbekkay M., Ferdaous G., Triki T. and Ferchichi A. (2012). Investigation of genetic variation in Tunisian date palm (Phoenix dactylifera L.) cultivars using ISSR marker systems and their relation with fruit characteristics. Turk. J. Biol., 36: 449-458.

Hossein K. H., Euring M. and Kharazipour A. (2015). Utilization of date palm (Phoenis dactylifera L.) pruning residues as raw material for MDF manufacturing. J. of Mater. Sci. Res., 4 (1): 46-62.

Marsafari M. and Mehrabi A.A. (2013). Molecular identification and genetic diversity of Iranian date palm (Phoenix dactylifera L.) cultivars using ISSR and RAPD markers. Aust. J. Crop Sci., 7 (8): 1160-1166. 
Moustafa A.A., Ibrahim Z.A., El-Yazal S.A.S. and El-Anwer M.A. (2010). Evaluation and selection of some seedling date palm males grown in Fayoum Governorate, Egypt. ISHS Acta Horticul. 882: IV international Date palm Conference.

Nasr T.A., Shaheen M.A. and Bacha M.A. (1986). Evaluation of date palm males used in pollination in the central region, Saudi Arabia. Date palm J., 8 : 163-175.

Nei M. and Li W. (1979). Mathematical model for studying genetic variation in terms of restriction endonucleases. Proc. Nat. Acad. Sci. USA 76 (10): 5269-5273.

Porebski S., Bailey L.G. and Baum B. R. (1997). Modification of a CTAB DNA extraction protocol for plants containing high polysaccharide and polyphenol components. Plant MoL Biol. Rep., (15): 8-15.

Ream C.L. (1976). Metaxinia effect of pollen from inbred male palms on ripening period and size of date fruit. Date Growers Inst. Rep. 53: 221-226.

Saker M.M., Adawy S.S., Mohamed A.A. and El-Itriby H.A. (2006). Monitoring of cultivar identity in tissue culture-derived date palms using RAPD and AFLP analysis. biologia Plantarum 50:198-204

Santos L.F., Oliveira E.J., Silva A.S., Carvalho F.M., Costa J.L. and Padua J.G. (2011). ISSR markers as a tool for the assessment of genetic diversity in Passiflora. Biochem.Genet. 45: 540-554.

Schwartz G. (1978). Estimating the dimensions of a model. Annals of Statistics 6: 461464.

Sedra M.H., Lashermes P., Trouslot P., Combes M.c. and Hamon S.(1998). Identiication and genetic diversity analysis of date palm (Phoenix dactylifera L.) varieties from Morocco using RAPD markers. Euphytica 103: 75-82.

Sneath P. H. A. and Sokal R.R. (1973). Numerical Taxonomy. Freeman, San Francisco, California, USA .

Snedecor G.W. and Cochran W.G. (1972). Statistical Method. $6^{\text {th }}$ ed Iowa State University Press, Ames., Iowa, U.S.A., $593 \mathrm{pp}$.

Soliman S.S., Ali B.A. and Ahmed M.M.M. (2003). Genetic comparisons of Egyptian date palm cultivars (Phoenix dactylifera L.) by RAPD-PCR. African Journal of biotechnology 2: 86-87.

Trii M., Rhouma A. and Marrakchi M., 2000.

Phylogenetic relationships in tunisian date palm (Phoenix dactylifera L.) germplasm collection using DNA ampliication ingerprinting. Agronomie 20: 665-671.

Zehdi S., Sakka, H. Rhouma A., Ould M.S.A., Marrakchi M. and Trii M. (2004a). Analysis of Tunisian date palm germplasm using simple sequence repeat primers. African Journal of biotechnology 3: 215-219.

Zehdi S., Trii M., Billotte N. Marrackhi M. and Pintaud J.C.(2004b). Genetic diversity of tunisian date palms (Phoenix dactylifera L.) revealed by nuclear microsatellite polymorphism. Hereditas 141: 278-287.

Zeinab A.M. Abo-Rekab, El-Kafrawy T.M. and Ghada A.A. (2014). Selection of good male date palm pollinators for improving both yields and fruit quality, using morphological characterization and genetic relationships of pollinators using ISSR markers. Sci. J. Flowers \& Ornamental plants. 1 (1):55-71. 


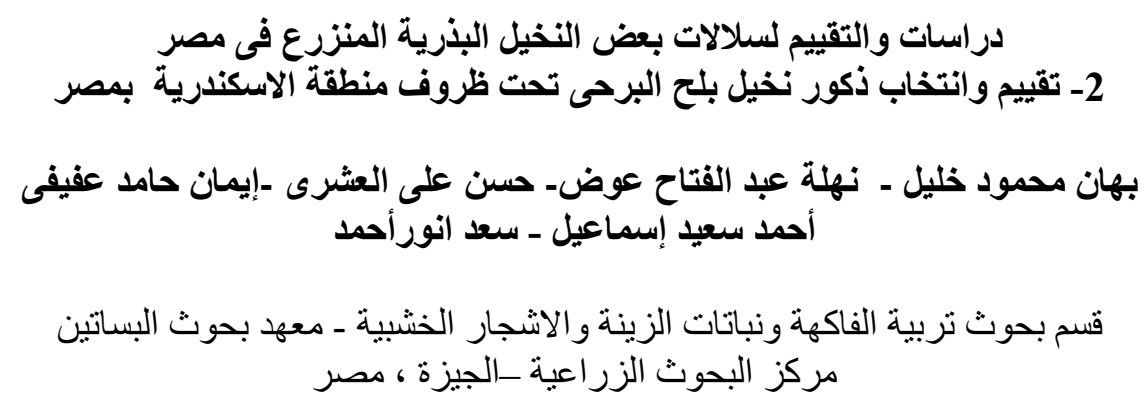

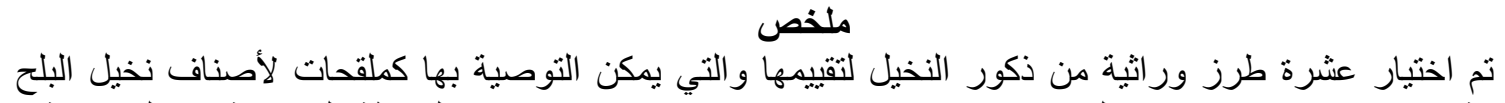

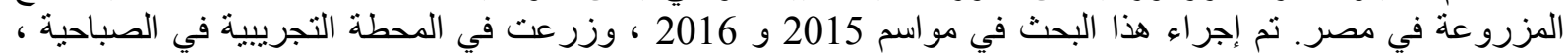

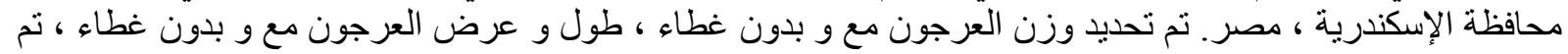

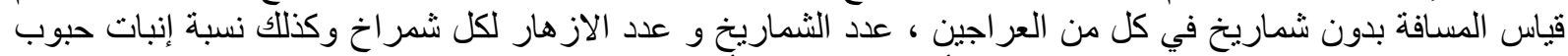

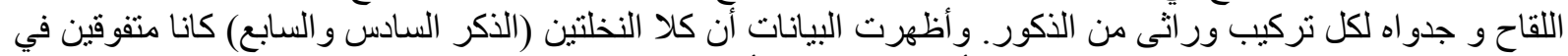

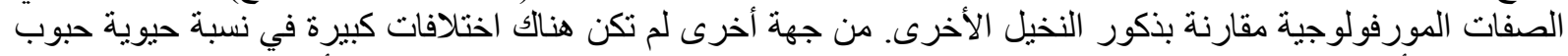

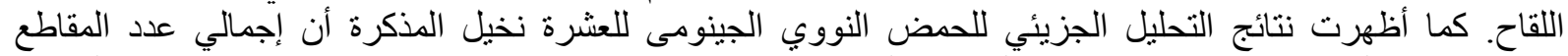
amplicons

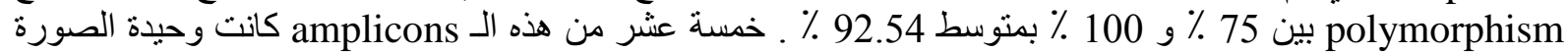
monomorphic

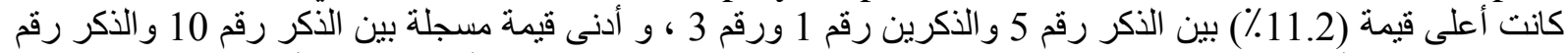

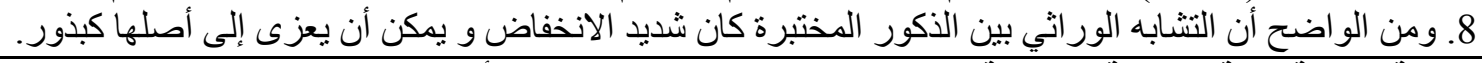

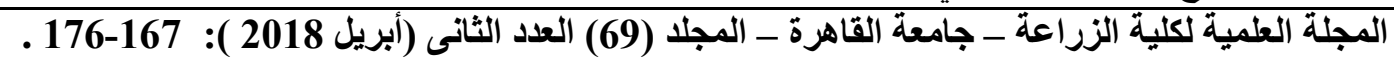

